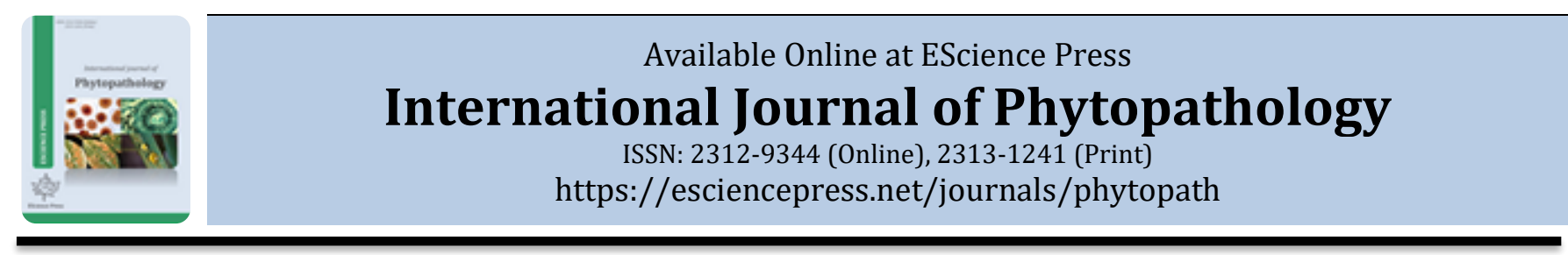

\title{
A DATE PALM DISEASE (BUNCH BLIGHT) CAUSED BY ACREMONIUM STRICTUM (CEPHALOSPORIUM) IN SAUDI ARABIA
}

\author{
Mohammad F. Rashed* \\ Plant Pathology Research Institute, Agricultural Research Center, Giza, Egypt.
}

*Corresponding Author Email: dmfawzy@windowslive.com

\section{A B S T R A C T}

Acrimonium strictum is reported as a new causal agent of a disease it names (bunch blight) in date palm (phoenix dactylefera) in Saudi Arabia. Symptoms and necrosis caused by A. strictum in susceptible cultivars showed small brown necrosis streak at midrib of fruit stalk in an early stage. There was an increase in number and size as the disease progresses; then extended to the bases of fruit strands due to death of bases and strands wilt, the infection of fruit strand caused drying the fruits and their fall. A. strictum attacks the bunches and move quickly inside and out the tissues causing brown necrosis and death of the tissues. A. strictum was isolated and pathogenicity tests were repeated more than once during two seasons and the identifications was caried several ways to confirm The confirmation of results by Biolog technique and DNA sequence were done. The proper temperature for infection was between $20-30{ }^{\circ} \mathrm{C}$ and the optimum $25^{\circ} \mathrm{C}$. When testing the susceptibility of varieties of infection, more varieties like Medjool, Saqae and Kholas were susceptible to infection and the most resistant to infection were Barhy and Khidri. The best results in the control of the fungus in vitro were due to use of Karpendazem followed Topsen M70, at the same time, the worst results were seen with the use of Abredion followed Karant (Cupper hydroxide).

Keywords: Acrimonium, date palm, Fruit stalk, Fruit strand, Bunch, Biology, DNA.

\section{INTRODUCTION}

Date palm (Phoenix Dactylefera L.) is a very important tree in the Arab world and Saudi Arabia is not an exception but it is more important with the great variation of varieties. The palm tree bears an average of 10 fruits, and when the fruit is infected, the loss in the crop is $10 \%$. The fruit is affected by diseases such as inflorescence decay caused by Mauginiella scaettae which affects the flowers directly, and then the crop (Ibraheem, 1984). The second disease that we are studying (bunch blight) caused by A. strictum which affects at fruit strands which bears the fruits (The symptoms scored for the first time by El-Meleigi (2004) in Saudi Arabia, but the record that causes Fusarium moniliforme). Brown and Karl (1938) maintained an inflorescence blight attacks several varieties and ages of date palms in southern Arizona, two species of Fusarium (F. monilijorme and F. semifectum) cause the blight, working together or separately. Klotz and Fawcett (1932) have found that Typical lesions are dark brown to black, hard, carbonaceous, and in mass give the petioles, midrib, fruit strands, and fruit stalks a scorched appearance, which suggests black scorch as the common name caused by Thielaviopsis paradoxa. It is known that the recorded diseases of date palms such as Bayoud caused by $F$ oxysporum f. sp. albedinis, black scorch caused by $T$. paradoxa, Diplodia disease caused by Deplodia phoenicum and Botryodiplodia theopromae (Barakat et al., 1992). Inflorescence decay caused by M. scaettae, T. paradoxa and F. moniloforme then Graphiola leaf spot caused by Graphiola phoenicis (Ibraheem, 1984; Alzayat, 2002). Date palm is affected by all diseases that affect the growth and the productivity. A new disease bunch blight which affects the crop directly because it causes the welt of the fruit strands. Rashed and Abdel Hafeez (2001) are reported $F$. moniliforme. causing deterioration of date palm and attack all the foliar of date palm (leaves, fruit stalks, bunches). $A$. strictum is pathogenic to many monocotyledonous and dicotyledonous crops, causing leaf desiccation on one side of the midrib of these plants, plant wilt and abnormal, discolored vasculature of the stalk near the soil line 
(Specht, 1989), Vasculature of the plant forms orange, red and brown bundles, usually resulting in death. Infection of A. strictum is systemic, and the fungus can be isolated from all tissues of the plant. Isolates have been found in plant seeds, which is probably the route of dissemination of the fungus and the crops affected by A. strictum include Acacia, Ficus, Glycine, Gossypium, Triticum and Zea. Because of its ubiquitous presence in soils, $A$. strictum negatively impacts many agricultural plants (El-Shafey et al., 1979).

\section{MATERIALS AND METHODS}

Area of study: A study was carried out in Awqaf Al Rajhi Date Palm Research Center- Plant Disease Department Al Kharj-Al Riyadh Saudi Arabia to assess the pathogenicity caused by A. strictum in our date palm This study was conducted during the period from February 2015 to June 2016 in Al Kharj province. It consisted of 20 date palm field in Al Kharj and Al Qaseem. The total number of date palm trees was estimated to be around 230000 trees with the total area about 1500 ha and production of about 5000 tons.

Isolation and identification: Samples of infected tissues of symptomatic trees represents fruit stalks, strands of infected trees collected from $\mathrm{Al}$ Kharj and Al Qaseem province, kept in plastic bags then transferred to the laboratory (in Al-Kharj) for investigation. Individually samples were cut into small pieces $0.5 \mathrm{~cm}$, surface sterilized for $2 \mathrm{~min}$ in a sodium hypochlorite solution (1.5\%), washed twice with sterile distilled water and placed on Potato Dextrose Agar (PDA) and incubated for 37 days at $26^{\circ} \mathrm{C}$. emerged parts from the tissue pieces were transferred to PDA and incubated at $26^{\circ} \mathrm{C}$ for 7 days. The single spore was transferred to a PDA slant and stored at 4 ${ }^{\circ} \mathrm{C}$ for further studies. Colonies were described according to morphological characteristics. Specific keys and references are used to identify the fungi to the genus level according to the taxonomic systems (Barnett and Hunter, 1972). Isolates will be deposited in the ARC PPRI Fungi Lab. 25/8/2015 and GSFMO, KSA for further identification using Biology technique (Singh, 2009) and DNA sequence (Pryce et al., 2003) Biology and Molecular Identification: Filamentous fungi are known to have unique biochemical pathways. The Biology FF Microplate was recently introduced for rapid identification of common filamentous fungi based on their abilities to utilize 95 discrete substrates. The substrate utilization fingerprints were useful in selecting media components for media optimization of secondary metabolite production for the various cultures. In general, a strong correlation was found between substrate utilization, growth, antimicrobial activity and presence of the responsible secondary metabolites. The method was used for replication of isolated fungi and in the differentiation of closely related variants within one species. The isolates were grown on $2 \%$ malt agar for 5 days and then processed according to Singh (2009). The identification was confirmed by the molecular tool. DNA sequence-based approach for the accurate in the same time identification of fungi by sequencing polymerase chain reaction (PCR) products with a rapid automated capillary electrophoresis system. A simple DNA extraction method and PCR amplification using universal fungal primers was used to amplify ribosome DNA from a range of isolates and reference strains. The internal transcribed spacer (ITS) DNA region was sequenced using automated dye termination sequencing. This identification was conducted according to Pryce et al. (2003).

Evaluate the pathogenic capability: Pathogenicity tests were conducted invitro on healthy detached fruit stalks of date palm. Healthy cuttings $25 \mathrm{~cm}$ long of the middle part of fruit stalks of Kholas cultivar were surface sterilized with $70 \%$ ethyl alcohol. The desired fungus well grown on PDA medium in Petri dishes for seven days at $28{ }^{\circ} \mathrm{C}$. For inoculation, pieces of the desired fungal growth were inserted into artificially made wounds ( $5 \mathrm{~mm}$ long $x 3 \mathrm{~mm}$ deep) made at the centre of fruit stalks cuttings. Proper controls were also prepared using PDA agar plug without pathogen. Three replicate were used for each treatment. All inoculated cutting of fruit stalks were kept in plastic boxes supplemented with wet cotton at room temperature according to the methods described by Molan et al. (2009) and Barakat et al. (1992). The size of damaged affected tissues around the point of inoculation was measured (mm) 10 days after inoculations as follow.

$$
\text { Area }=\text { Width } \times \text { Length }
$$

Effect of temperature: The pathogenicity tests were done in the effect of temperature, but the inoculated parts were incubated at different temperatures such as 17, 20, 25,30 and $35{ }^{\circ} \mathrm{C}$, ( 3 replicates for each temperature degree), the results were obtained after 15 days of incubation.

Susceptibility of the varieties: Pathogenicity tests were carried out on several cultivars such as Barhi, Kholas, Saqaey, Medjool and Khadri. They were incubated at 25 ${ }^{\circ} \mathrm{C}$. The results were taken after 15 days of incubation. The results were calculated by measuring the area of the spot caused by the fungus. (means of three replicates for each 
treatment).

In-vitro evaluation of different fungicides against Acremonium strictum: The efficacy of non-systemic fungicides and systemic fungicides against Acrimonium strictum were assessed by poisoned food technique (Sharvelle, 1961). Required quantities of individual fungicides based on active ingredients were added separately into potato dextrose agar (PDA) to get the desired concentration of the fungicides. Later $25 \mathrm{ml}$ of the poisoned medium was poured into sterile Petri plates. Mycelial discs of five mm size from an actively growing culture of the fungus were cut out by a sterile cork borer and one such disc was placed at the center of each PDA plate. Control was maintained without adding any fungicides to the medium. Each treatment was replicated thrice. Then plates were incubated at $26 \pm 1{ }^{\circ} \mathrm{C}$ for nine days and radial colony growth was measured. The efficacy of a fungicide was expressed as percent inhibition of mycelia growth over control that was calculated by using the formula given by Vincent (1947). The percent values were converted to arc sin transformations, the data were analyzed statistically.

$$
I=\frac{(C-T)}{C} \times 100
$$

Where, I= Percent inhibition. $\mathrm{C}=$ Radial growth in control $(\mathrm{mm})$. $\mathrm{T}=$ Radial growth in treatment.

Fungicides used in this trial as follow: Topsin M70
(Thiophanatmethyl 70\%), Carbandazim (Carbandazim 50\%), Corva (Abredion 50\% and Carant (Cupper hydroxide $77 \%)$ - Concentrations/ppm $(10,30,50,100)$ for each fungicide.

\section{RESULTS AND DISCUSSION}

Natural symptoms: As shown in Figure $1 \mathrm{a}, \mathrm{b}$ and e the pathogen attacks fruit stalks causing elongated brown color and then extends longitudinally and internally causing necrosis of tissues and the parasite attacks the bases of fruit strands (Figure 1c and f) causing brown necrosis then deterioration leads to the death of the tissues and drying of fruit strands and fruits (Figures $1 \mathrm{~d}$ and $\mathrm{f}$ ). Microscopic studies were also studied (Figure 1g-i).

Pathogenicity test: The pathogenicity test showed the severity of the infection with A. strictum, where the symptoms extend from the place of the inoculum on the fruit stalk until twenty-five centimeters then deteriorated fruit strands, it bases and all the bunch (Figure $2 \mathrm{~d}$ ). After twenty-five days of artificial infection Figure 2a noninoculated, there is no symptoms, while in Figure $2 b, c$ with fungus, the symptoms were clear after 15 days of inoculum. In the same time in Figure 2d The result obtained after 25 days, there was a development of infection and the symptoms included fruit stalk and fruit strand completely. Re-isolated from a distance of 25 centimeters from the place of the first inoculum was conducted. These symptoms are severe and are similar to inflorescence infection with $F$. moneliforme and $F$. semetictum, which cause the inflorescence decay (Brown and Butler, 1938).
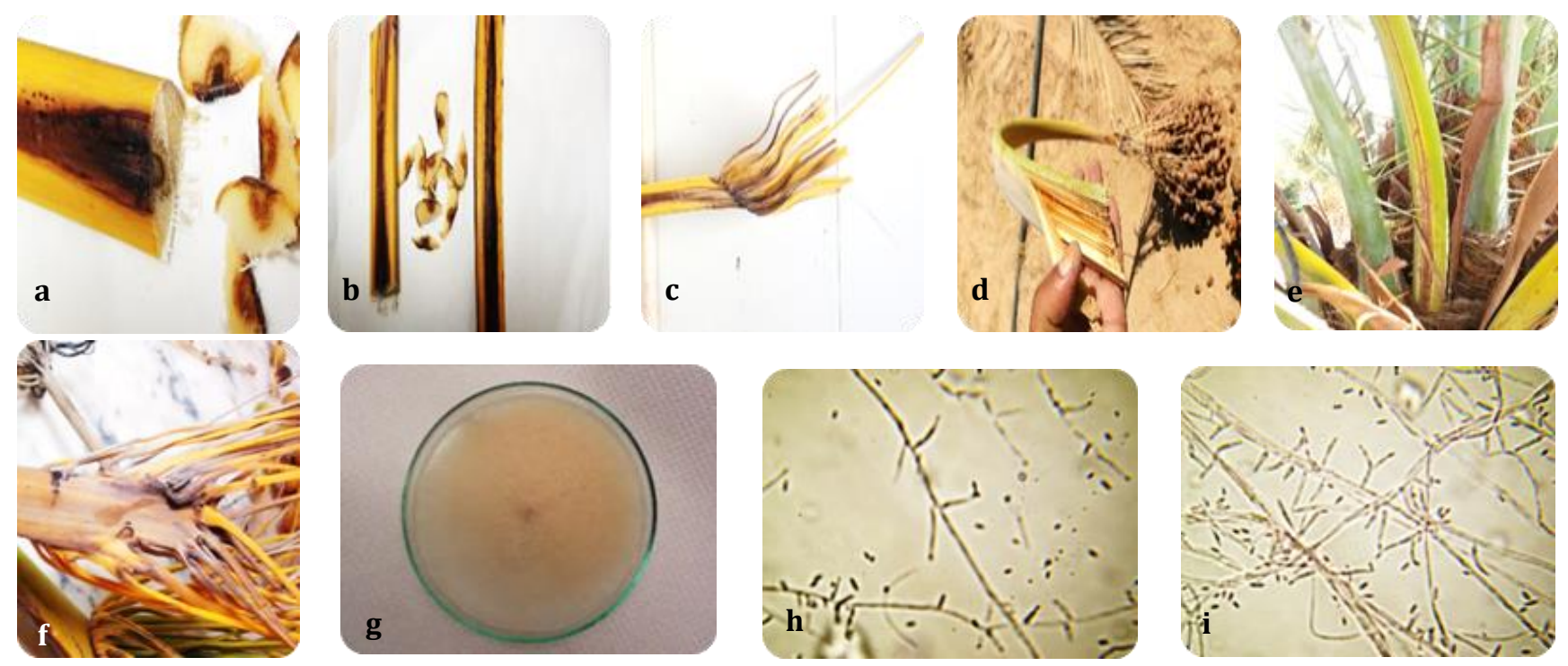

Figure 1. The symptoms a, b, e; cleared the brown necrosis extends external and internal of fruit stalk, c; connected with the bases of fruit strands, in severe infection, d, f; Showed deterioration of the bunch and losses of the fruits, g; culture plate, h, I; microscopic picture of the A strictum. 

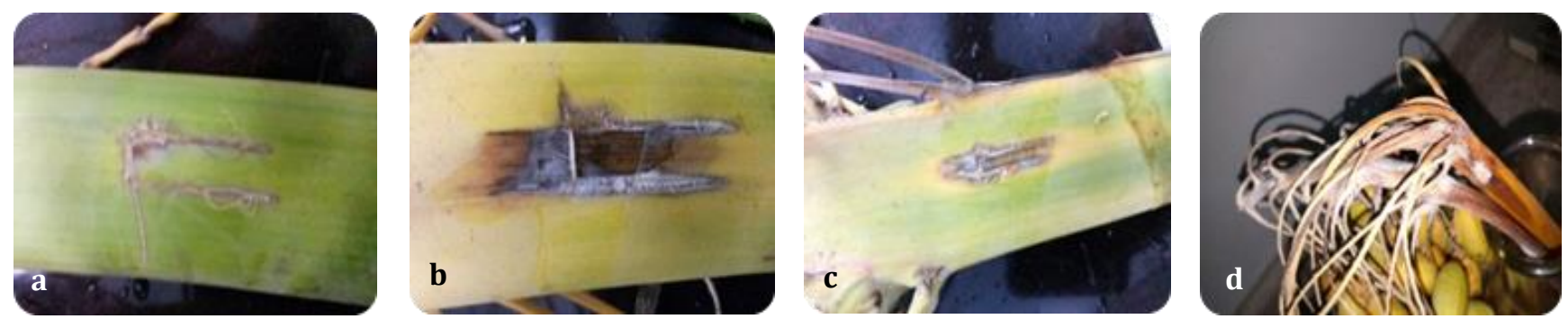

Figure 2. a; control plant, b, c; treated plants after 15 days, d; treated plants after 25 days.

The fungus is similar in shape and behaviour $F$. moniliforme, especially the imperfect stage from Acrimonium (Cephalosporium) (Barnett and Hunter, 1972). F. monileforme was isolated from the bunches of date palm which showed the same symptoms of infection by El-Meleigi (2004) has been called the disease wilt of fruit bunch.
Effect of temperature: From Table 1 it is clear that the infection spread in a wide moderate temperature range, which is the time of the differentiation of fruit stalk and the emergence of flowers and the holding of fruits of date palm during February, March and April in Saudi Arabia, which means that the activity of the pathogen coincides with the activity of flowering, pollination and fruit.

Table 1. area of lesion after 15 days of inoculated of fungus and incubated under different temperatures.

\begin{tabular}{llllll}
\hline Temperatures & $17^{\circ} \mathrm{C}$ & $20^{\circ} \mathrm{C}$ & $25^{\circ} \mathrm{C}$ & $30^{\circ} \mathrm{C}$ & $35^{\circ} \mathrm{C}$ \\
\hline Area of lesion & $50 \mathrm{~mm}$ & $90 \mathrm{~mm}$ & $140 \mathrm{~mm}$ & $130 \mathrm{~mm}$ & $60 \mathrm{~mm}$ \\
\hline
\end{tabular}

Varietal susceptibility: It is clear from the results that the most sensitive cultivars of infection was Medjool that shown maximum lesion size that was $180 \mathrm{~mm}$ (Figure 3d), followed by Saqaey showed $150 \mathrm{~mm}$ lesion size (Figure 3c) while Kholas showed $125 \mathrm{~mm}$ lesion size (Figure 3b) while the least sensitive was Barhi (Figure 3a) and Khidry Figure 3e cultivars showed $25 \mathrm{~mm}$ lesion size (Table 2). A. strictum has been shown to be involved in some myoparasitic relationships, as well as a wide range of plant endophytic and parasitic relationships (RiveraVaras et al., 2007) and further studies, are required to determine $A$. strictum's use as a biological control agent and role as a parasite that reduces crop yields. A. strictum exhibits metabolism of many products that imply future agricultural and pharmaceutical significance (Chen et al., 2007; Chang et al., 2013), It appears that the temperature range that suits the infection of A.strictum is associated with similar fungi that affect date palms as $F$. moniliforme (Ammar et al., 2004) and (Rashed and Abdel Hafeez, 2001).

Disease Control (In vitro studies): It is clear from Table 3 that the highest inhibitory of fungus was with Karpendzim followed by Tobsen (thiphanatmethyl) and that the least inhibitory was with the Carant (copper hydroxide) pesticide and this is consistent with Rashed et al. (2007) and Rashed (2014) in the treatment of palm diseases systemic pesticides, especially Topsin and Carbendezim.

Table 2. area of the lesion after 15 days of inoculated of the pathogen in different of date palm cultivars and incubated under $26^{\circ} \mathrm{C}$.

\begin{tabular}{llllll}
\hline Cultivars & Barhi & Kholas & Saqaey & Medjool & Khidry \\
\hline Area of lesion $\mathrm{mm}$. & 25 & 125 & 150 & 180 & 25 \\
\hline
\end{tabular}
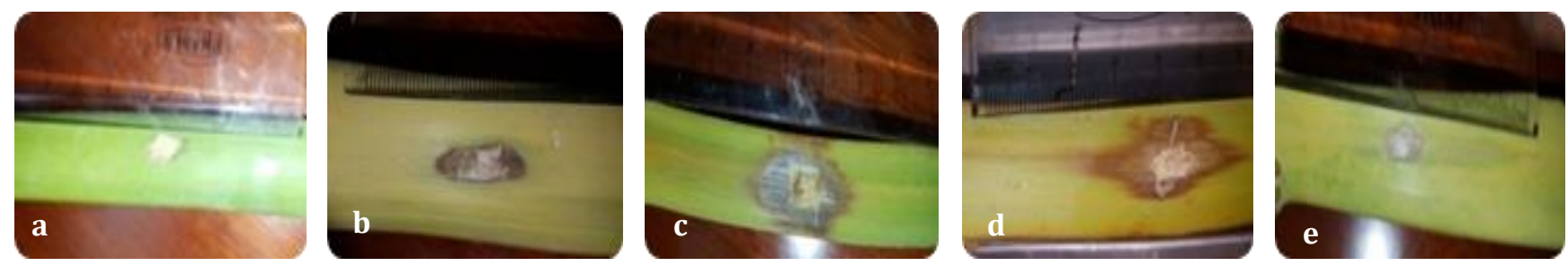

Figure 3. a; Barhi, b; Kholas, c; Saqaey, d; Medjool, e; Khidry verities. 
Table 3. Evaluation of different fungicides against Acremonium Strictum.

\begin{tabular}{|c|c|c|c|c|}
\hline \multicolumn{5}{|c|}{ Means of linear growth of A. strictum (mm.) } \\
\hline \multicolumn{5}{|c|}{ Fungicides (A) } \\
\hline Concentrates (B) & Carbendazim & TopsinM $_{70}$ & Corval & Carant \\
\hline 10ppm & 7.0 & 12.0 & 29.5 & 80.0 \\
\hline $30 \mathrm{ppm}$ & 7.0 & 10.5 & 35.3 & 80.0 \\
\hline $50 \mathrm{ppm}$ & 7.0 & 7.7 & 32.3 & 80.0 \\
\hline $100 \mathrm{ppm}$ & 7.0 & 7.0 & 31.8 & 75.0 \\
\hline
\end{tabular}

\section{REFERENCES}

Alzayat, M. 2002. Pastes and diseases of date palm in Saudi Arabia and its control. In, 369. F.A.O. and Ministry of agriculture Saudi arabia Al Riyadh, King Fahd library.

Ammar, M., K. MA and R. MF. 2004. Basal leaf-stalk rot of tissue culture date palm caused by Fusarium moniliforme. Egyptian Journal of Applied Sciences, 19: 23-24.

Barakat, F., K. Sabet and S. Hussein. 1992. Pathological studies on the deterioration of date palm offshoots caused by Botryodiplodia theobromae. Bulletin of Faculty of Agriculture, Cairo University (Egypt), 43: 395-410.

Barnett, H. L. and B. B. Hunter. 1972. Illustrated genera of imperfect fungi. Illustrated genera of imperfect fungi.

Brown, J. and K. D. Butler. 1938. Inflorescence blight of the date palm. Journal of Agricultural Research, 57: 313-18.

Chang, J., Y. Tani, H. Naitou, N. Miyata and H. Seyama. 2013. Fungal Mn oxides supporting Mn (II) oxidase activity as effective Mn (II) sequestering materials. Environmental technology, 34: 278187.

Chen, G.-T., M. Yang, Y. Song, Z.-Q. Lu, J.-Q. Zhang, H.-L. Huang, L.-J. Wu and D.-A. Guo. 2007. Microbial transformation of ginsenoside $\mathrm{Rb} 1$ by Acremonium strictum. Applied Microbiology and Biotechnology, 77: 1345-50.

El-Meleigi, M. 2004. First report on two new diseases of date palm (Phoenix dactylifera), rachis blight caused by Seranomyces californica and wilt of fruit bunch caused by Fusarium moniliforme in Saudi Arabia. In: International Conference on Date Palm, 49-61. King Saud University, Saudi Arabia.

El-Shafey, H., M. Abd-El-Rahim and M. Refaat. 1979. A new Cephalosporium-wilt disease of grain sorghum in Egypt. In: Egyptian Phytopathology Congress, Cairo (Egypt), 26-29 Nov 1979. The Egyptian Phytopathology Society.

Ibraheem, K. 1984. Regional Project for Palm and Dates Research Centre in the Near East and North Africa. Final report [on date palm orchards in Iraq](November 1982-March 1984).

Klotz, L. and H. Fawcett. 1932. Black scorch of the date palm caused by Thielaviopsis paradoxa. J Agric Res, 44: 155-66.

Molan, A. L., S. De and L. Meagher. 2009. Antioxidant activity and polyphenol content of green tea flavan-3-ols and oligomeric proanthocyanidins. International journal of food sciences and nutrition, 60: 497-506.

Pryce, T. M., S. Palladino, I. D. Kay and G. W. Coombs. 2003. Rapid identification of fungi by sequencing the ITS1 and ITS2 regions using an automated capillary electrophoresis system. Medical Mycology, 41: 369-81.

Rashed, M. 2014. Tip dieback disease of date palm leaves in Egypt. Journal of Biological Chemistry and Environmental Sciences, 9.

Rashed, M. and N. Abdel Hafeez. 2001. Decline of date palm trees in Egypt. In: 2nd International Conference on Date Palm, 25-27.

Rashed, M., F. M. Barakat and K. K. Sabet. 2007. Evaluation of some fungicides and biocontrol agent to control black scorch disease of date palm caused by Thielaviopsis paradoxa. In: 4th Symposium on Date Palm, 315. Saudi Arabia.

Rivera-Varas, V. V., T. A. Freeman, N. C. Gudmestad and G. A. Secor. 2007. Mycoparasitism of Helminthosporium solani by Acremonium strictum. Phytopathology, 97: 1331-37.

Sharvelle, E. G. 1961. The nature and uses of modern fungicides Burgess Publishing Company.

Singh, M. P. 2009. Application of Biolog FF MicroPlate for 
substrate utilization and metabolite profiling of closely related fungi. Journal of Microbiological Methods, 77: 102-08.

Specht, L. P. 1989. Sporulation and Survival of Conidia ofCephalosporium gramineumas Influenced by
Soil pH, Soil Matric Potential, and Soil Fumigation. Phytopathology, 79: 787.

Vincent, J. M. 1947. Distortion of fungal hyphæ in the presence of certain inhibitors. Nature, 159: 85050 .

Publisher's note: EScience Press remains neutral with regard to jurisdictional claims in published maps and institutional affiliations.

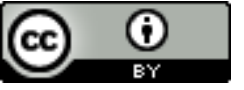

Open Access This article is licensed under a Creative Commons Attribution 4.0 International License, which permits use, sharing, adaptation, distribution and reproduction in any medium or format, as long as you give appropriate credit to the original author(s) and the source, provide a link to the Creative Commons license and indicate if changes were made. The images or other third-party material in this article are included in the article's Creative Commons license, unless indicated otherwise in a credit line to the material. If material is not included in the article's Creative Commons license and your intended use is not permitted by statutory regulation or exceeds the permitted use, you will need to obtain permission directly from the copyright holder. To view a copy of this license, visit http://creativecommons.org/licenses/by/4.0/.

(C) The Author(s) 2018. 